\title{
BURUNG GARUDA DALAM SENI KRIYA
}

\author{
Dedy shofianto ${ }^{1}$ \\ (shofiantodedy@gmail.com, Kriya KayuPascasarjana Institut Seni Indonesia Yogyakarta)
}

\begin{abstract}
Garuda is an eagle bird that becomes Indonesian national symbol, famous with the slogan Bhineka Tunggal Ika. Garuda is chosen as a source of wood craft creation starts from the idea of writer to take a closer look about a phenomenon of the people of Indonesia nowadays. Slogan Bhineka Tunggal Ika means "unity in diversity". However, Indoneisan people in this moment are deeply devided by various conflicts such as; religions, cultures, socials, and also politics. The form of Garuda in this creation will go to a deformation become kinetic work. The Garuda with dynamic movement in this creation is different with static Garuda that we commonly see.

This artwork creation is using several theories as a basis creation. The first theory is phenomenology by Kuswarno with subjectivism approach. This theory is used to see phenomenon that happens in Indonesia. The second one is aesthetic theory, for aesthetic and social function which is the main stake. Third, creativity theory by Rhodes, it stated that creativity commonly is formulated in the term "Four P's Creativity", which is one thing, interrelated within person, process, press, and products. Creation method in this work uses practice based research. In the practice process, these several stages, exploration, experiment, and execution are applied.

The finding outcome in this creation is the fact that different to kinetic work in common, this work is stimulated by mechanic technique and electronic which produce sensor. Therefore, the audience could do interaction directly with the art work. This creation produce five artwork consists of three panel works, and two 3D artwork. Each work has different meaning but has one same correlated concept. The artwork which is created produce a new character of Garuda by combining forms of machine mechanic such as gears, bolts, with electronic devices. All those artwork is dominated by wood, while still showing the character of Garuda and the meaning behind Garuda. Besides, this artwork is also able to represent creativity potency as well as innovation and education in the world of art.
\end{abstract}

Key Words: Garuda, deformation, Kinetic art, wood craft.

\section{ABSTRAK}

Burung garuda merupakan simbol negara Indonesia yaitu garuda Pancasila dengan semboyan Bhineka Tunggal Ika. Garuda diangkat sebagai sumber penciptaan kriya kayu ini berawal dari penulis melihat fenomena keadaan bangsa Indonesia pada saat ini. Semboyan Bhineka Tunggal Ika memiliki arti "berbeda- beda tetapi tepat satu" akan tetapi, bangsa Indonesia pada saat ini berpecah belah dikarenakan suatu konflik agama, budaya, sosial, serta politik. Bentuk garuda dalam penciptaan ini akan mengalami suatu deformasi menjadi karya kinetik, pada umumnya kita melihat garuda dengan bentuk statis akan menghasilkan gerakan yang dinamis dalam karya ini.

Penciptaan karya ini menerapakan beberapa teori sebagai landasan penciptaannya. Pertama teori Fenomenologi dari Kuswarno dengan pendekatan sudut pandang subjektivisme, teori ini sebagai cara melihat fenomena yang terjadi saat ini di Indonesia. Kedua teori estetika, teori ini sebagai fungsi estetika dan sosial merupakan pokok utama. Ketiga teori kreativitas dari Rhodes bahwa kreativitas pada umumnya dirumuskan dalam istilah "Four P's Creativity", yaitu suatu hal yang saling berelasi antara person, proses, press, dan Products. Sementara metode penciptaan menggunakan penelitian berbasis praktek pada bagian proses prakteknya dilakukan tahapan eksplorasi, eksperimen dan eksekusi. 
Hasil temuan dari penciptaan ini yaitu, berbeda dengan kinetik pada umumnya karya ini digerakan dengan teknik mekanik dan elektronik yang akan menghasilkan sensor, sehingga penikmat seni dapat secara langsung berinteraksi dengan karya. Sementara itu dalam tahapan perwujudan karya digunakan beberapa teknik dikriyakayuuntuk memperlihatkan nilai estetika dalam karyanya. Penciptaan ini menghasilkan lima karya yang terdiri dari tiga karya panel dan dua karya tiga dimensi. Setiap karya memiliki makna yang berbeda tetapiadakorelasi konsep yang sama. Karya yang diciptakan menghasilkan karakter baru Garuda dengan memadukan bentuk-bentuk mekanik mesin seperti roda gigi, baut, dengan perangkat elektronik. Semua karya tersebut di dominasi dari kayu dengan tetap memperlihatkan karakter $\mathrm{G}$ aruda dan makna yang terkandung di dalam Garuda. Selain itu juga mampu menghadirkan potensi kreatifitas serta inovasi dan edukasi dalam dunia kesenian.

Kata kunci: Garuda, deformasi, seni kinetik, kriya kayu

\section{PENDAHULUAN}

Perjalanan hidup manusia tidak lepas dari tindakan berkesenian, hal tersebut selalu hadir dalam pemenuhan kebutuhan hidup manusia. Aktivitas berkesenian tumbuh dan berkembang seiring dengan latar belakang kehidupan manusia, sehingga seni menjadi berkembang dengan berbagai aliran yang sesuai dengan kehendak, selera dan latar belakang budayanya masing-masing. Karya seni merupakan hasil ciptaan manusia yang mengungkapkan pengalaman batin atau pangalaman estetik dari seorang seniman (Soedarso 200 : 2), sementara itu karya seni diciptakan dalam upaya memenuhi kebutuhan fungsional maupun keindahan. Aliran-aliran seni yang berkembang saat ini di antaranya adalah seni kinetik.

Seni kinetik adalah seni yang melibatkan gerakan, tetapi tidak semua seni yang melibatkan gerakan berarti kinetik. Menurut pendapat Dharsono (2004:118), Gerakan itu sendiri sebagai bagian yang integral dengan karyanya. Sementara itu dalam istilah seni rupa, seni kinetik disebut pula dengan kinetic art, berasal dari bahasa Yunani 'kinesis' atau 'kinetikos', yang berarti 'gerak' digunakan untuk menjelaskan karya-karya yang berhubungan dengan 'gerak' (movement, motion) dalam berbagai bentuknya, demikian pendapat dari Edwin Galery (2015). Seni kinetik gerak menjadi salah satu unsur - unsur visual, seperti bentuk dan warna.

Kekinian dalam seni atau disebut seni kontemporer modern saat ini begitu pesat mempengaruhi perkembangan seni di Indonesia. Kinetic art atau dikenal juga dengan seni kinetik merupakan salah satu media baru dalam bidang seni rupa. Karya yang ditunjukkan merupakan perpaduan antara seni dan teknologi dengan "gerakan" sebagai tema utamanya.

Di Rusia setelah perang dunia I, gagasan tentang seni kinetik muncul pertama kali oleh beberapa seniman: Tatlin, Rodchenko, Naum Gabo, dan Pavsner. Mereka berusaha mengedepankan gagasan tersebut dengan simultan, kemurnian dan kekuatan. Di benua Eropa dan Amerika, kinetik art ini berkembang setelah masa Perang Dunia II. Seni kinetik dianggap sebagai suatu respon artistik para seniman terhadap adanya rasionalitas, ilmu pengetahuan dan teknologi (http://senikinetic.tumblr. com).

Di Indonesia, era 1990-an merupakan saat kemunculan gairah artistik yang timbul sebagai terobosan baru dalam upaya keluar dari batas-batas medium yang pada masa sebelumnya cenderung dominan. Dengan 
popularitas instalasi dan performan, elemen gerakan muncul dalam tingkat sensibilitas yang berbeda. Utamanya melalui persinggungan dengan budaya dan tradisi semacam seni pertunjukan (teater dan wayang), artefak tradisional, dan juga pada benda-benda keseharian.

Edwin Rahardjo, salah seorang pelopor seni kinetik di Indonesia berusaha mempopulerkan aliran seni tersebut dengan memprakarsai sebuah galeri, yaitu Edwin's Gallery. Galeri ini mewadahi aspirasi seni kinetik yang menggabungkan seni tiga dimensi dan prinsip mekanik. Kehadiran karya Edwin Rahardjo seolah menunjukkan bagaimana spektrum praktik seni kinetik di Indonesia mampu membuka kemungkinan adanya kolaborasi yang menarik antara seni dan teknologi.

Estetika kinetic art, kini telah hadir sebagai suatu metafor dari sebuah narasi, kinerja suatu sistem mekanik, serta motif artistik yang berdiri sendiri. Lebih mendasar adalah pentingnya untuk memahami bagaimana ketertarikan mata penikmat karya seni pada sebuah kesan gerakan pada dasarnya wakil bagi sifat manusia alamiah.

Penciptaan karya seni kriya kayu sebagaimana ide yang dituangkan oleh penulis, berupa karya seni kriya kayu tiga dimensi dan prinsip mekanik dengan mengambil berbagai elemen dari wujud Garuda, serta menggabungkan dengan prinsip mekanik dari segi ekspresi. Dalam mewujudkan karya ini, banyak mengambil ide visual dari karya-karya seniman yang telah ada sebelumnya dalam batasan sebagai refrensi, di ataranya karya-karya Rudi Hendriatno, Edwin Raharjo, Bob Potts yang menampilkan seni kinetik di dalam ide karyanya. Karya-karya seniman yang telah disebutkan digunakan sebagai rujukan pertimbangan subjektif untuk referensi ide penciptaan.
Sementara dalam tataran teknik karya banyak menggunakan teknik yang ada di kriya kayu di antaranya, teknik kerja bangku, ukir, bubut, scroll saw, dan sebagainya dengan menggabungkan teknik mekanik dan elektonik untuk mempertimbangkan ketercapaian bentuk dan gerak. Penciptaan karya ini lebih mengedepankan ketercapaian ide yang ingin diungkap pada visual karya, di samping keunikan bentuk, juga menekankan pada gerakan yang dihasilkan dari teknik perwujudan yang diterapkan.

Karya penciptaan kriya kayu ini sengaja mendeformasi burung Garuda untuk mendeskripsikan mengenai keadaan bangsa Indonesia. Ada beberapa pendapat yang menganggap bahwa, Burung Garuda hanyalah mitos belaka. Burung Garuda tidak dikenal di wilayah geografis Indonesia, akan tetapi dikenal lewat peradaban India yang diambil alih oleh peradaban Jawa. Ditemukan beberapa artefak bermotif Burung Garuda, seperti pada candi Garuda di Candi Wisnu, kompleks Candi Prambanan yang menyimpan kisah tentang manusia setengah burung bernama Garuda. Dari kisah tersebut, walaupun burung Garuda bukan berasal dari Indonesia, akan tetapi digunaka sebagai lambang negara. Penggambaran seekor burung raksaksa yang dinamakan sebagai Burung Garuda Pancasila dengan semboyan Bhineka Tunggal Ika. Lambang negara Indonesia berbentuk burung Garuda yang kepalanya menoleh ke sebelah kanan heraldik, perisai berbentuk menyerupai jantung yang digantung dengan rantai pada leher Garuda, dan semboyan Bhinneka Tunggal Ika yang berarti "Berbedabeda tetapi tetap satu" ditulis di atas pita yang dicengkeram oleh Garuda.

Hal-hal yang telah dipaparkan penulis di atas, melatar belakangi pengambilan tema burung garuda dengan ide karya seni kinetik dalam karya penciptaannya. Agar menghasilkan 
suatu makna yang sesuai, bentuk, dan gerakan yang akan diwujudkan dalam karyanya. Sehingga karya ini akan menciptakan suatu deskripsi ungkapan estetika dan dapat diapreasiasi penikmat seni sesuai konsep dasar yang diharapkan.

Penciptaan karya ini memiliki tujuan yang ingin di capai yaitu karya dengan ide dasar Garuda dengan berbagai konsep didalamnya. Selain konsep bentuk Garuda, karya diciptakan juga bisa bergerak dan berinteraksi dengan pengunjungdikarenakan, menggunakan sensor gerak sebagai media penghubung karya dan pengunjung. Hal ini akan memberikan manfaat yang berkaitan dengan edukasi, budaya dan seni.

\section{TUJUAN DAN MANFAAT}

Tujuan dari peciptaan karya ini adalah Mengetahui nilai historis dan makna filosofis Garuda yang dijadikan sumber inspirasi dalam penciptaan karya seni. Kedua menciptakan karya seni berbentuk Garuda dengan cara mekanik menggunakan bahan kayu. Ketiga menjadikan karya seni kriya sebagai media berekspresi dan sarana untuk mengintropeksi diri melalui konsep karya yang diciptakan.

Manfaatnya adalah Sebagai media perenungan akan keadaan Indonesia. Kedua menambah inovasi dan kreasi inspiratif dalam pengembangan alternatif karya seni kriya. Ketiga memberikan inspirasi dengan media baru melalui objek Garuda yang lebih kreatif dan inovatif di tengah arus perkembangan seni kriya.

\section{KAJIAN SUMBER PENCIPTAAN}

Sumber penciptaan karya ini, akan mengambil beberapa sumber referensi terkait mengenai Garuda dan dokumentasi dari karya seni kinetik. Garuda sebagai objek karya seni rupa, didominasi oleh sutau kecenderungan untuk mencari siapa pencipta rancangan tersebut. Dalam dunia akademisi adanya suatu gejala dimana dibalik karya yang monumental terdapat seorang seniman hebat yang menciptakan karya itu. Berbalik belakang dari paparan tersebut, penulis ingin menciptakan suatu karya seni kinetik dengan objek Garuda yang dikombinasikan dengan perangkat elektronik yang mampu berinteraksi dengan pengunjung. Agar hasil yang diharapkan dapat tercapai, penulis menggunakan beberapa data acuan sebagai sumber inspirasi karyanya.

Garuda merupakan lambang negara Indonesia disebut juga dengan Garuda Pancasila. Garuda sendiri tak asing bagi bangsa Indonesia karena merupakan satu ikonik, dimana Garuda merepresentasikan negara Indonesia. Menurut pendapat Hidayah (2008:5) menyatakan bahwa, Garuda Pancasila adalah burung Garuda yang dapat dijumpai pada beberapa bangunan candi yang ada di Indonesia terutam di Pulau Jawa. Beberapa pengamat dan peneliti menyebutkan bahwa ada anggapan burung Garuda hanya makhluk mitos belaka. Hal ini disebabkan burung Garuda tidak dikenal di wilayah geografis Indonesia, akan tetapi dikenal lewat peradaban yang ada di India yang masuk ke Jawa hingga terjadinya asimilasi kultural. Motif Garuda dapat ditemukan pada peninggalan budaya terdahulu seperti pada Candi Garuda di Candi Wisnu, kompleks Candi Prambanan yang menyimpan kisah mistik tentang manusia setengah burung bernama Garuda. Sementara itu pada awalnya lambang negara Indonesia terinspirasi dari mitos Garuda yang terdapat di beberapa candi, baik dalam bentuk arca maupun relief. 


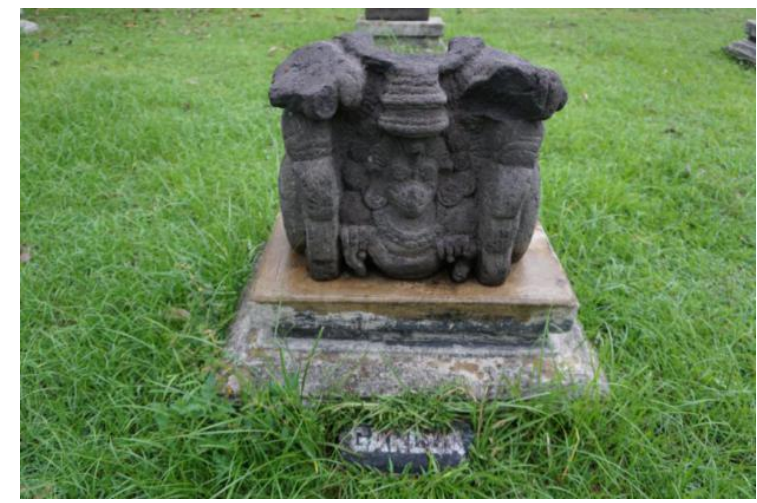

Gambar 1. Arca patung Garuda di komplek Candi Prambanan.

Sumber: Dokumentasi pribadi Dedy shofianto, 2020

Bentuk dari Garuda Pancasila tidak mengambil keseluruhan bentuk dari burung Garuda, akan tetapi berdasarkan mitologi serta gambar yang terdapat pada relief maupun artefak pada Candi di Indonesia. Deskripsi dari burung Garuda berasal dari burung elang rajawali. Dalam buku milik Hidayat (2008), mengenai "Mencari Telur Garuda", mengatakan bahwa Garuda adalah suatu istilah yang dipakai dalam mitologi untuk merepresentasikan burung elang rajawali, sementara bentuk aslinya adalah burung elang rajawali, hal ini sama dengan persepsi masyarakat Indonesia akan wujud dari burung Garuda itu sendiri.

Elang Jawa (Spizaetus bartelsi) disebut sebagai burung nasional Indonesia, karena kemiripannya dengan burung Garuda yang menjadi lambang negara Indonesia. Burung ini adalah burung epidemik Jawa berukuran sedang sekitar $60 \mathrm{~cm}$. Dalam bahasa Inggris, elang Jawa disebut Javan Hawk-eagle, merupakan salah satu jenis burung pemangsa terlangka di dunia dan merupakan raja dari para burung, yang dikenal sebagai simbol dari kekuasaan yang besar dan kegagahan.

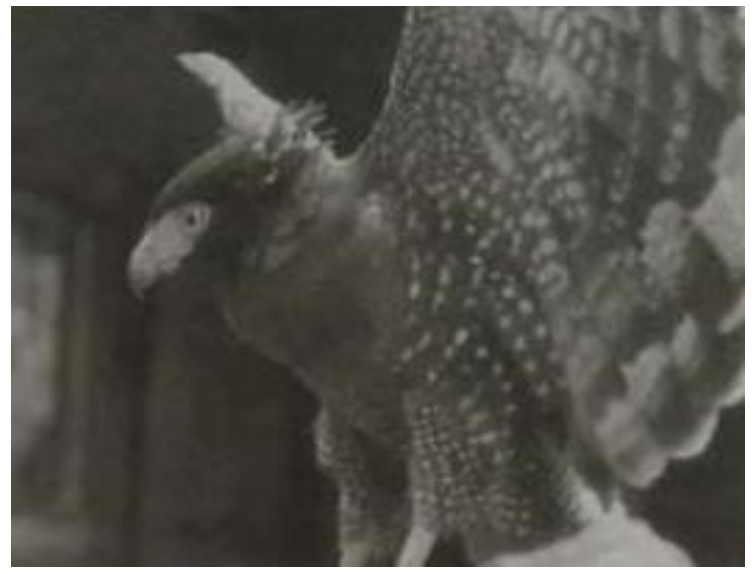

Gambar 2. Elang Jawa Spizaetus Bartelsi Sumber: Hidayat, 2009: 9.

Indonesia memiliki banyak ikon yang dapat mewakili tentang negara Indonesia, seperti penggunaan bahasa Indonesia, kain batik, habitat yang terdapat Indonesia dan lain sebagainya. Sama halnya dengan lambang negara Garuda Pancasila. Garuda Pancasila dapat dikatakan sebagai ikon dari negara Indonesia. Pertama adalah dengan adanya penggunaan burung Garuda, yang kemudian dikenal dengan burung elang Jawa dan telah dinobatkan sebagai maskot satwa langka dari Indonesia pada tahun 1993 yang merupakan habitat asli dari daerah di kawasan Indonesia. Penggambaran burung Garuda pada Garuda Pancasila memiliki spesifikasi, seperti bulu sayap yang berjumlah 17 helai dan bulu ekor 8 helai. Angka yang muncul pada lambang ini memberikan indikasi tentang hari kemerdekaan dari Indonesia, yaitu 17 Agustus atau bulan ke-8. Ketetapan dari jumlah bulu Garuda ini dapat ditemukan padal lampiran peraturan pemerintah No. 66 Tahun 1951 pasal 3. Warna yang terdapat pada penggunaan lambang negara Indonesia, yaitu kuning keemasan dapat menjadikannya sebagai indeks. Warna ini memberikan indikasi tentang keinganan negara Indonesia atau visi dan misi Indonesia, yaitu untuk menjadi negara yang bijaksana, agung dan 
dihormati oleh negara lain. Pernyataan ini dapat ditemukan pada Penjelasan atas Peraturan Pemerintah no.66 Tahun 1951 tentang lambang negara (Hidayat, 2008: 101). Kepala burung Garuda yang menghadap kekanan merupakan sebuah indeks dari sifat baik. Sementara posisi kepala yang lurus merupakan ikon dari sifat negara Indonesia yang tidak ambisius, sombong, semena-mena dan memandang masalah secara lurus. Penggambaran posisi kepala ini dipengaruhi oleh perancang dari lambang negara, yaitu Panitia Lencana Negara yang didominasi oleh orang Jawa dan dikerjakan di pulau Jawa sehingga tradisi yang digunakan adalah tradisi yang berasal dari pulau Jawa.

Dalam pendapat Soekatno (1992), tradisi pewayangan Jawa terdapat tiga istilah tentang posisi kepala yaitu, posisi luruh berarti menunduk ke bawah, longok berarti memandang ke depan, dan langak berarti agak menengadah, memandang agak ke atas. Luruh mempunyai karakter tenang, sabar, tak tergesagesa segala tindakannya. Kebalikan dai karakter ini adalah karakter dari posisi langak. Sedangkan posisi longok adalah berada diantara kedua karakter ini. Secara garis besar tokoh pewayangan di Indonesia dibagi menjadi dua, yaitu tokoh baik dan tokoh jahat. Tokoh baik dapat pula disebut sebagai wayang kanan dan tokoh jahat disebut sebagai wayang kiri. Tokoh baik berada di sebelah kanan dalang dan tokoh jahat berada disebelah kiri dalang. Tokoh kanan selalu menunjukkan sifat-sifat keutamaan, keteladanan bagi manusia.

Pengertian sisi kanan di Indonesia dalam Ensiklopedi Nasional Indonesia adalah dalam politik, merupakan bagian dari ideologi, paham, dan aliran tertentu dalam suatu gerakan politik. Istilah kanan diartikan sebagai sekelompok orang yang duduk di sebelah kanan raja pada sidang pleno kerajaan, dan mereka merupakan kelompok pendukung monarki absolut. Dalam perkembangan selanjutnya, istilah ini mulai dipakai pula oleh negara-negara lainnya. Pada umumnya, kelompok yang berhaluan kanan ini terdiri atas kaum puritan atau bangsawan yang ingin mempertahankan sistem monarki absolut. Sebelah kanan, bagi kebiasaan bangsa Indonesia adalah lambang kebaikan, langkah mujur, kepercayaan, kekuatan. Sedangkan sebelah kiri melambangkan langkah sial, lambang kejahatan dan serong.

Kepala Garuda yang menoleh lurus ke kanan ini menjadikannya sebagai indeks yang memiliki pengertian bahwa negara Indonesia adalah sebuah negara yang tidak tergesa-gesa ataupun ambisius dalam mengambil keputusan dan melihat permasalahan secara lurus. Selain itu negara Indonesia merupakan negara yang memiliki kepercayaan, kebaikan serta kekuatan untuk menjadi negara yang besar.
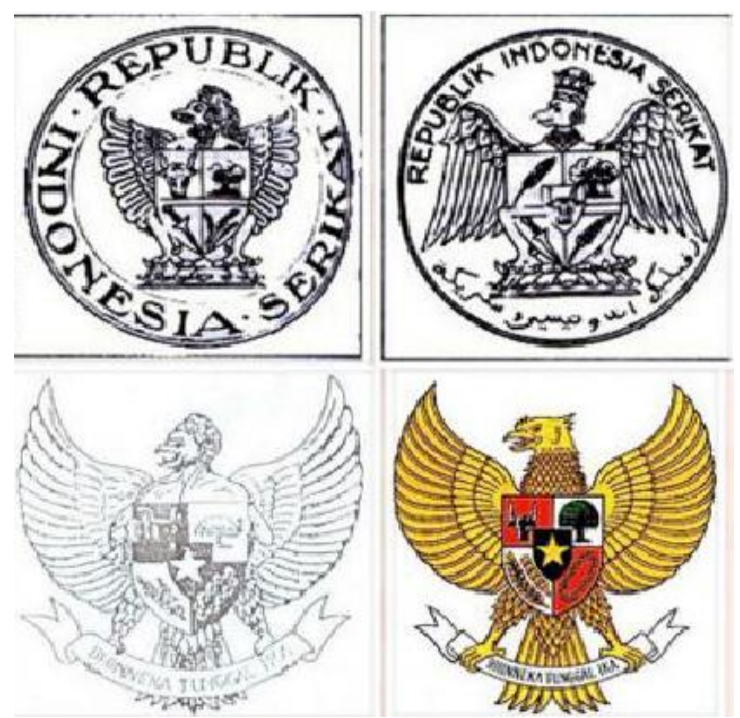

Gambar 3. Rancangan awal lambang Negara Indonesia Sumber: Hidayat, 2008: 7.

Garuda Pancasila ditetapkan sebagai lambang negara Indonesia sejak 1950. Sebagai lambang negara, burung Garuda digambarkan sedang menoleh ke sebelah kanan dari sudut 
pandang Garuda dan kedua kakinya mencengkeram pita bertuliskan Bhinneka Tunggal lka.

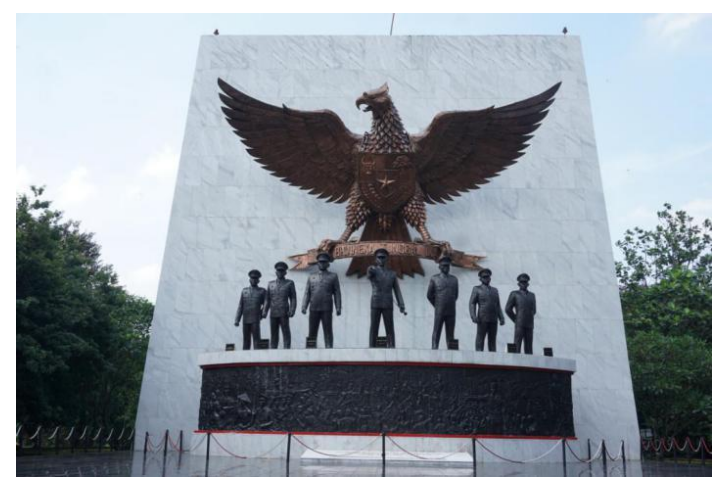

Gambar 4. Patung monumen Pancasila Sakti. Sumber: Dokumentasi pribadi Dedy shofianto, 2020

Tugu Monumen Pancasila Sakti terletak 45 meter (melambangkan tahun kemerdekaan Indonesia) sebelum utara cungkup sumur maut. Patung pahlawan revolusi berdiri dengan latar belakang sebuah dinding setinggi 17 meter (melambangkan tanggal kemerdekaan Indonesia) dengan hiasan patung Garuda Pancasila. Dinding berbentuk trapesium tersebut berdiri diatas landasan yang berukuran $17 \times 17 \mathrm{~m} 2$ dengan 7 anak tangga menuju pelataran (melambangkan 7 Pahlawan Revolusi). Ketujuh patung Pahlawan Revolusi berdiri berderet dalam setengah lingkaran dari barat ke timur yaitu: Patung Mayjen TNI Anumerta Soetojo Siswomihardjo, Mayjen TNI Anumerta D.I. Panjaitan, Letjen TNI Anumerta R. Soeprapto, Jendral TNI Anumerta Ahmad Yani, Letjen TNI Anumerta M.T. Harjono, Letjen Tni Anumerta A. Parman, Kapten Czi Anumerta P.A. Tendean. Ketujuh patung berdiri pada alas yang berbentuk lengkung dengan hiasan relief yang melukiskan peristiwa prolog, kejadian dan penumpasan G 30 S/PKI oleh ABRI dan rakyat.

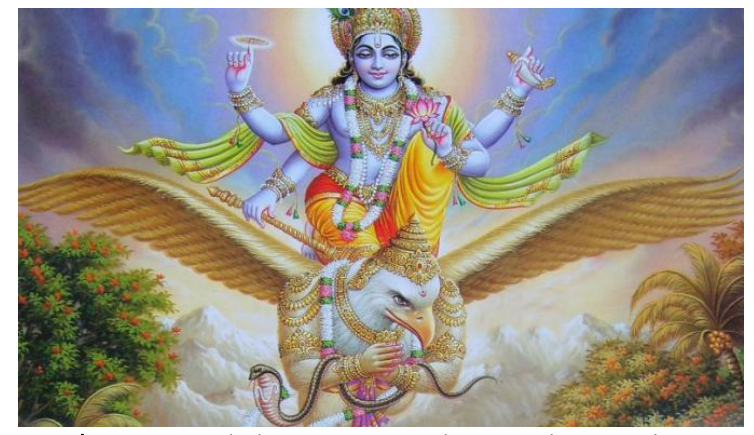

Gambar 5. Garuda burung mistis dari Mitologi Hindu yang berasal dari India.

Sumber: http://phdi.or.id/artikel/garuda-panca-sila-bagiumat-hindu, 2017

Selain garuda sebagai objek karya nantinya, penulis berinspirasi penciptaan karya dengan menggunakan seni kinetik dalam proses perwujudan karya. Dalam proses karya ini tidak membuat bentuk asli dari objek Garuda akan tetapi adanya suatu perubahan dalam karyanya. Perubahan yang akan dilakukan berupa pengembangan baru dengan meninjau tampilan dari segi konsep, bahan, bentuk, dna fungsinya.

Setelah mengamati, mengumpulkan data, dan melihat secara langsung beberapa bentuk Garuda yang ada, penulis tertarik menuangkannya ke dalam karya seni kinetik. Melihat nilai estetika yang terdapat dari Garuda, seperti yang diungkapkan oleh Sudarmaji (1979:17), yaitu:

"Secara ilmu jiwa yang pertama lahirnya karya seni adalah pengamatan peristiwa. Pengamatan sesungguhnya bukan peristiwa yang lepas dan berdiri sendiri karena seorang mengamati suatu objek maka ada stimulasi (rangsangan) yang selanjutnya seorang akan menangkap suatu makna objek tersebut sesuai dengan pengamatan.

Pada masa Renaissance, ide digunakannya gerakan mekanik telah ada pada masa itu. Hal ini dapat dilihat pada karya Loenardo daVinci dalam aktivitas kesehariannya, beliau pernah mendesain bebrapa karya 
mekanik untuk hiburan para pangeran dan berbagai festival di kota besar. Seperti kita ketahui, Loenardo da Vinci pernah mendesain mesin terbang yang pertama. Mimpi untuk terbang seperti seekor burung adalah mimpi yang setua umat manusia itu sendiri. Namun belum ada yang memburunya intensitas, kegigihan, dan komitmen pada riset yang teliti, sebagaimana Leonardo da Vinci. Sains tentang penerbanganya melibatkan banyak disiplin mulai dari fluida hingga anatomi manusia, mekanika, anatomi burung, teknik mekanis (Ismanto, 2005 :243).

Dalam pendapat Zaelani (2013), mengatakan bahwa adanya perbendaharaan istilah dan konsep seni rupa, istilah 'seni kinetik' (kinetic art, dari bahasa Yunani 'kinesis' atau 'kinetikos', yang berarti 'gerak') digunakan untuk menjelaskan karya-karya yang berhubungan dengan 'gerak' (movement, motion) dalam berbagai bentuknya. Sejak dikemukan pada abad 20, praktik seni kinetik telah melampaui definisi karya dengan melihat teknik dan gaya tertentu. Secara umum, hal ini berkaitan dengan perkembangan dari sudut pandang, respons, dan pemahaman para seniman terhadap konsep serta fenomena 'gerak'.

Awal mula seni kinetik mulai ada pada masa perkembangan seni pantung. Jejak awal kinetic sculpture dalam seni patung bisa ditelusuri dari karya Max Bill, Construction with Suspended Cube (1935-1936), yang memperkenalkan ide persepsi gerak, walaupun objeknya sendiri tidak menghasilkan gerak, demikian pendapat dari Scheneckenburger (2005:500-501). Hal ini dipertegas pada era konstruksionisme oleh Naum Gabo yang memperkenalkan istilah kinetic rhytm. Perkembangan teknologi yang menyebabkan persinggungan seni dengan teknologi dan pesatnya kemajuan dunia komputer (digital) membuat suatu pehitungan rumit untuk dilakukan. Akhibat hhal tersebut, membuat karya seni kinetik berkembang menjadi lebih kompleks. Seperti pada karya Theo Jansen, misalnya, berhasil meleburkan antara seni dan teknologi, dan menciptakan 'artificial intelligent' dengan pendekatan revolusioner.

Perkembangannya teknologi dan teknik elektronik bukan hanya sarana dan keterampilan untuk memperluas batas artistik tetapi suatu metode dan media ekspresi untuk mengembangkan bentuk. Oleh karenanya, teknologi elemen tidak dapat ditarik dari karya. Teknologi dan seni memiliki status yang sama. Agar seni kinetik berkembang secara pesat, seni ini tergantung pada teknologi dan perkembangan hubungan dengan eksistensi teknologi, sehingga dapat menghasilkan suatu wujud berupa aplikasi yang kreatif, inovasi, dan dapat mengekspresikan ide tersebut.

Sementara itu, struktur informasi, prinsip prosedural, dan kontrol umpan balik yang ditekankan dalam teknologi elektronik adanya suatu pemikiran kreatif seniman, membuat hubungan kerja sama antara seni kinetik dan teknologi bahkan lebih penting dari pada sebelumnya, demikian pendapat dari Guang-Dah (2015 : 927).

Dari pemaparan di atas dapat dilihat dari salah satu seniman terkenal asal Belanda, Theo Jansen, menggelar pameran seninya di Asia Tenggara, tepatnya di Singapura. Beliau menampilkan koleksi Strandbeests melalui pameran interaktif yang bertajuk Wind Walkers: Theo Jansen's Strandbeets kepada pengunjung Art Science Museum. Strandbeests merupakan hasil karyanya yang berupa mesin bertenaga angin. Hasil karyanya adanya suatu perpaduan antara seni, sains, dan pertunjukan. Dalam bahasa Belanda, Strandbeest memiliki arti 'binatang pantai' sehingga karya ini didesain 
Jansen untuk berkeliling pantai, serta mendorong dan menumpuk pasir pantai yang nantinya akan dapat melindungi garis pantai. Selain itu karya ini akan ditampilkan di Animaris Siameses yakni raksasa yang memiliki berat lebih dari 200 kg dengan panjang 72 kaki.

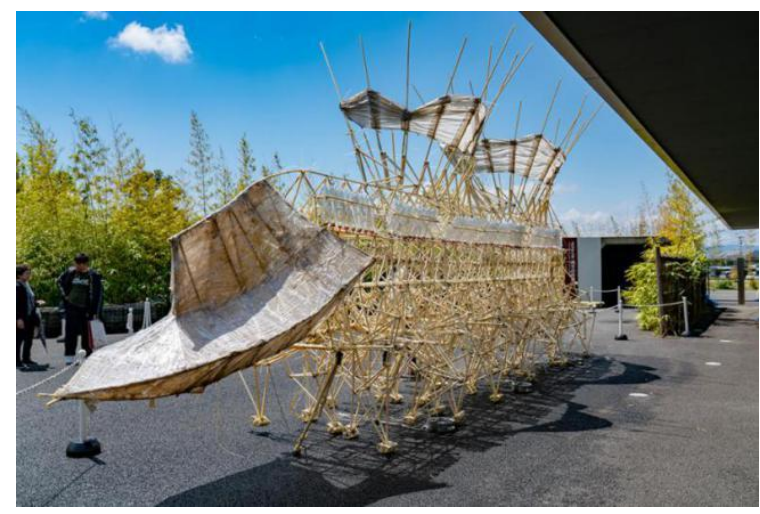

Gambar 6. karya Theo Jansen "Strandbeests" sumber:

https://singaporeguidebook.com/2018/07/09/strandbeest s-hasil-karya-theo-jansen-dipamerkan-di-singapura/, 2020.

Di Indonesia, istilah seni kinetik tergolong kurang populer. Meskipun berbagai aspek 'gerak' bisa kita temukan dalam beberapa karya seniman Indonesia khususnya dalam karya-karya yang selama ini populer dengan sebutan 'instalasi'. Ada salah satu pemaran yang didatangi penulis yang membahas mengenai Motion/Sensation di Edwin Gallery Jakarta pada tahun 2013. Pameran ini digagas dengan tujuan melacak berbagai gagasan dan bentuk 'gerak' dalam karya para seniman Indonesia yang berkembang dengan skala kecil. Selain didorong oleh kebutuhan untuk melihat eksperimentasi baru, pameran ini adalah upaya untuk mengkaji seni kinetik sebagai suatu medium.

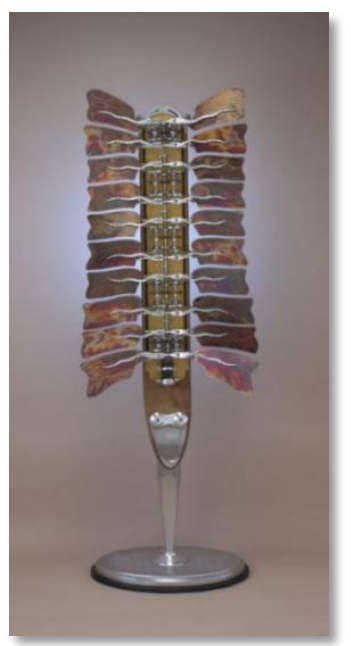

Gambar 7. Karya Edwin Raharjo "LIGHT RHYTHM"

Teakwood, alumunium dural, brass, bronze , 2013. Sumber :http://indoartnow.com/artists/edwin-rahardjo, 2017.

Seni kinetik yang berkembang di Indonesia memiliki suatu keunikan tersendiri, dan berbeda dengan seniman yang berada di luar. Dalam perkembangan seni kinetik sebagian besar dalam wujud karya seni instalasi, hal ini dikarenakan banyaknya penggunaan media lokal yang disesuaikan dengan tema yang berkaitan dengan kehidupan sosial masyarakat yang dikombinasikan dengan nilai tradisional dan modern yang mengikuti perkembangan zaman hal ini terlihat baik dari segi tema maupun teknik yang digunakan. Seperti pada contoh salah satu seniman Yogyakarta yaitu Heri Dono, dalam karya terlihat adanya suatu kombinasi antara teknologi dengan menggunakan dinamo serta suara digunakan sebagai pengerak elemenelemen estetika. 


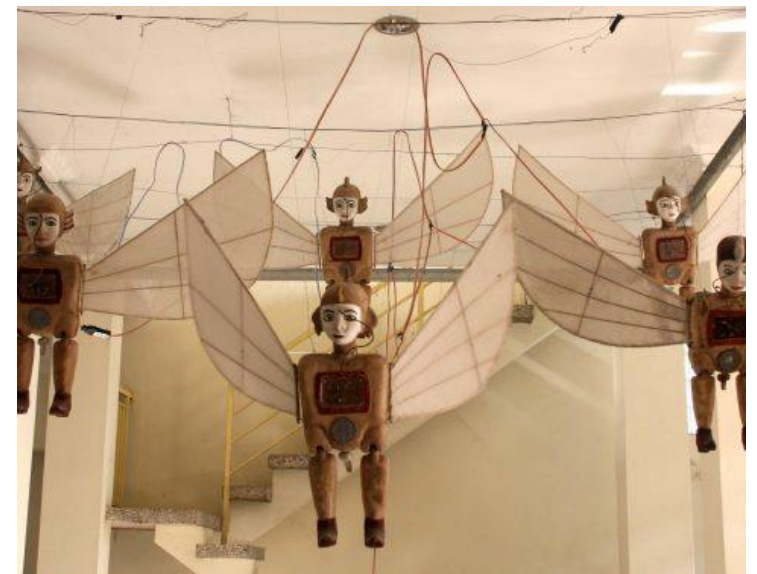

Gambar 8. Karya Heri Dono "Flying Angels" fiberglass, bamboo, fabric, mechanical device,1996. Sumber: http://heridono.com/portfolio/1996/, 2020.

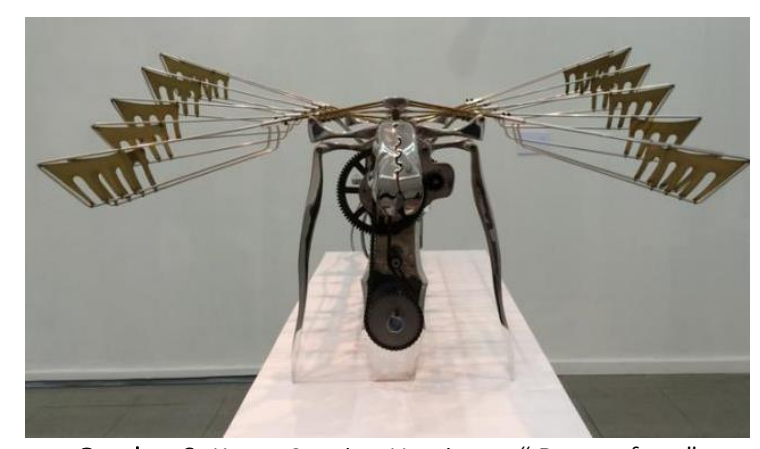

Gambar 9. Karya Septian Harriyoga "Dragonfrrry" Dural, Brass, Metal, Electric motor/Carving, 2012. Sumber: http://businesslounge.co.id/2014/10/30/sekilaskarya-karya-menarik-dalam-pameran-trienalversi/, 2017.

Berdasarkan data-data yang telah dijelaskan di atas adanya suatu relevansi dengan proses penciptaan karya ini. Melalui data-data literatur dan observasi terhadap burung Garuda, memberikan suatu nilai konseptual seperti menampilkan wujud Garuda yang akan dibuat dari berbagai perspektif baik segi estetika, historis, dan makna filosofinya. Penulis memperoleh data dari bentuk-bentuk Garuda yang ada pada artefak, burung elang Jawa, dan Garuda Pancasila. Ketiga jenis bentuk burung Garuda ini memiliki korelasi yang memperlihatkan budaya yang ada di Indonesia, sehingga dalam penciptaan karya ini akan menampilkan bentuk Garuda ciri khas unik bangsa Indonesia.
Dalam penciptaan ini burung Garuda akan mengalami suatu deformasi akan tetapi tetap memperlihatkan karakter dari burung Garuda baik dari segi kepala dan sayap Garuda. Melalui beberapa bentuk burung Garuda diharapkan akan menghasilkan suatu korelasi antara Garuda pancasila yang memperlihatkan identitas bangsa Indonesia, burung elang Jawa yang menunjukan bahwa garuda merupakan salah satu burung yang dimiliki bangsa Indonesia, serta Garuda yang ada pada artefak terdapat di candi akan menunjukan kebudayaan adanya suatu gejela pencampuran budaya dari bentuk Garuda.

Sementara dalam seni kinetik yang telah dipaparkan, bahwa seniman-seniman baik yang ada diluar maupun didalam Indonesia, telah menggunakan dan mengembangkan seni kinetik. Pada seniman Belanda beliau memadukan antara seni, sains, dan pertunjukan dalama karyanya, sedangkan pada seniman di Indonesia menyebut seni kinetik sebagai seni instalasi atau kontemprer. Penulis mengamati adanya perbedaan antara seniman luar dan dalam di Indonesia yaitu dalam penggunaan bahan dan makna yang disampaikan. Seniman Indonesia cenderung menggunakan bahan lokal sebagai karyanya dan makna yang diambil seputar kehidupan sosial masyarakat Indonesia, sementara senimana luar menggunakan seninya upaya menjaga lingkungan. Akan tetapi walaupun punya konsep dan penggunaan bahan material yang berbeda para seniman tersebut memiliki suatu kesamaan dimana menggunakan seni kinetik dalam karyanya.

Berbeda dengan karya-karya yang telah dipaparkan dalam karya yang akan dihasilkan akan menggunakan gerak mekanik dan eletronik dalam karyanya yang akan menghasilkan gerak sensorik. Pada umunya karya yang terdahulu lebih menggunakan gerakan manual ataupun 
menggunakan dinamo sebagai penggeraknya. Sementara dalam karya yang akan dihasilkan penulis akan menggunakan gerak mekanik yang ada pada pergerakan jam yang dipadukan dengan teknik elektonik yang akan menghasilkan geraka yang lebih dinamis dengan menggunakan material kayu untuk mewujudkan karyanya.

Melalui data-data yang diperoleh karya akan diciptakan merupakan suatu perpaduan antara berbagai bentuk Garuda yang ada di Indonesia dengan memasukan unsur mekanik dan elektronik ke dalam wujud Garuda yang akan mengalami deformasi pada bagian badan, sementara pada bagian kepala dan sayap masih memperlihatkan bentuk dari Garuda hal ini dilakukan untuk mempertahankan wujud aslinya. Perpaduan gerak antara mekanik dan eletronik akan menghasilkan gerakan sensorik yang nantinya adanya suatu interaksi antara penikmat seni dengan karya ini. Hal ini dilakukan agar penikmat seni bukan hanya melihat tapi dapat pula berinteraksi langsung dengan karyanya.

\section{LANDASAN PENCIPTAAN}

Dalam penciptaan ini akan menggunakan beberapa teori sebagai landasan penciptaan, yaitu menggunakan teori estetika, dan teori kreativitas. Hal ini dilakukan untuk memperoleh hasil karya yang memperlihatkan aspek-aspek baik dari segi pemilihan bahan, teknik, bentuk, gerak, dan estetika dalam karya penciptaan ini. Berikut teori yang digunakan sebagai landasan penciptaan yaitu:

1. Fenomenologi

Pendekatan Fenomenanologi Kuswarno 2009 dalam (Sani, 2015:4), menyebutkan bahwa fenomenologi merupakan pendekatan dengan sudut pandang subjektivisme, yaitu melihat sesuatu bukan hanya dari suatu gejala, namun juga berusaha untuk menggali makna yang terdapat pada gejala tersebut. kesadaran merupakan cara berfikir yang mengarah pada suatu hal berdasarkan keinginan dan merupakan kesimpulan dari sebuah kesadaran.

Cara pandang fenomenologi semacam ini dianggap tepat oleh penulis dalam penciptaan karyanya. Fenomenologi menjelaskan mengenai persepsi atau sudut pandang, fenomenologi juga menjelaskan bagaimana seseorang berfikir dan menyadari keberadaan benda tersebut. Seperti apa yang disampaikan penulis pada penciptaan karyanya, Teori fenomenologi membantu menjelaskan mengenai sudut pandang penulis melihat fenomena keadaan bangsa Indonesia pada saat ini. Semboyan Bhineka Tunggal Ika memiliki arti "berbeda- beda tetapi tepat satu" akan tetapi, bangsa Indonesia pada saat ini berpecah belah dikarenakan suatu konflik agama, budaya, sosial, serta politik. Penciptaan ini penulis mencoba menuangkan ide "Garuda Dalam Karya Seni Kriya" sebagai riset bentuk-bentuk Garuda Yang Digabungkan dengan perkembangan teknologi kedalam sebuah karya seni. Bentuk garuda dalam penciptaan ini akan mengalami suatu deformasi menjadi karya kinetik, pada umumnya kita melihat garuda dengan bentuk statis akan menghasilkan gerakan yang dinamis dalam karya ini.

\section{Teori Estetik}

Penciptaan karya ini nantinya mengacuh pada wujud kriya seni yang meletakan fungsi estetika dna sosial sebagai fungsi utama, sementara itu untuk proses penciptaan ini menggunakan metode, teori estetika, dan teori tanda sebagai pendukungnya. Teori yang digunakan memiliki klasifikasi dan fungsi yang berbeda akan tetapi saling berkaitan satu dengan yang lainnya, yang akan diimplementasikan dalam karya ini. 
Penciptaan lambang negara Garuda Pancasila melalui proses yang cukup panjang. Proses lahirnya ideologi Pancasila telah banyak dikupas berbagai buku sejarah, namun hingga saat ini masih langka buku yang mengulas siapa pencipta lambang Garuda Pancasila. Menurut pendapat Pasha (2003: 57), mengatakan bahwa lambang Garuda Pancasila yang semula merupakan karya Sultan Hamid Al-Gadri ॥ setelah dibahas oleh "Panitia Lencana Negara"y ang diketuai oleh Muhamad Yamin akhirnya diterima dan disahkan menjadi konsep Lambang Negara Republik Indonesia.

Dalam proses perwujudan karya ini menggunakan seni kinetik yang nantinya, garuda akan mengalami suatu deformasi. Penggunaan teori estetika akan memperhatikan deformasi dari perubahan susunan bentuk dengan disengaja untuk kepentingan seni, dengan menggunakan 4 cara yaitu, menyederhanakan (simplifikasi), menggayakan (stilisasi), merusak (distorsi), dan kombinasi antara ketiganya (mix), demikian menurut Susanto (2011: 98). Sementara dalam pendapat Kartika (2004:42-3), mengatakan bahwa deformasi merupakan perubahan wujud sebuah bentuk, yang dibagi menjadi 4 macam yaitu, "stilisasi (menggayakan objek), distorsi (merusak objek), transformasi (menggabungkan objek), dan disformasi (menggambarkan sebagian objek)".

Perpaduan dari bentuk, warna, dan unsur seni rupa menciptakan harmoni yang menghasilkan susunan estetika. Pendapat Kartika (2004:11), suatu indah pada dasarnya terdiri dari kualitas pokok yang meliputi kesatuan, keselarasan, kesetangkupan, keseimbangan, dan perlawanan yang dapat diserap oleh inderawi. Dalam pendapat Soedarso (1990:39), mengatakan bahwa keindahan kita tangkap dengan indera. Melalui inderawi memiliki perbedaan dengan kegiatan yang dilakukan dengan perasaan ataupun dengan pikiran. Seperti yang diketahui bahwa seni tak selamahnya selalu indah, dengan tidak membatasan untuk mengali nilai keindahan seni melalui perasan dan pikiran. Dari apa yang telah dipaparakan dapat diambil benang merah bahwa, dalam menilai suatu keindahan terdapat tingkatan proses pengerapan, menurut Kartika (2004: 18), proses ini dibagi dalam berapa tingkatan pertama menilai unsur seni rupa, kedua menilai pengorganisasian unsur seni rupa, dan pada tingkatan ketiga adalah menilai konseptual karya. Melalui tahapan tersebut dapat membedakan penyerapan tentang indah, yaitu secara inderawi dan perasaan.

3. Teori Kreativitas

"Kreativitas" dalam pendapat Iswantara (2017), mendefinisikan kreativitas adalah kegiatan mental yang sangat individual yang merupakan manifestasi kebebasan manusia sebagai individu. Kreativitas adalah suatu kondisi, suatu sikap atau keadaan mental yang sangat khusus sifatnya dan hampir tak mungkin dirumuskan. Dikatakan sebagai manusia yang kreatif adalah manusia yang menghayati dan menjalankan kebebasan dirinya secara mutlak. Awal kreativitas adalah munculnya ketidakpuasan, kegelisahan atas lingkungan hidupnya dan kreativitas bertolak dari yang sudah ada seperti tradisi kebudayaannya masing-masing. Menurut pendapat Rhodes (2017:11-14) mengatakan bahwa kreativitas pada umumnya dirumuskan dalam istilah "Four P's Creativity", adanya tahapan yang saling berkaitan, yaitu pribadi (Person) yang melibatkan diri dalam proses (Process) kreatif dengan dorongan dan dukungan (Press) dari lingkungan menghasilkan produk (Product) kreatif. Pengertian kreativitas tergantung pada segi penekanannya, kreativitas dapat 
didefinisikan ke dalam empat jenis dimensi sebagai berikut :

a. Kreativitas dalam dimensi Person

Adalah upaya mengartikan kreativitas fokus pada individu atau person dari individu yang dapat disebut kreatif secara pribadi. Dalam penerapan kreativitas dalam dimensi person dalam proses penciptaannya yaitu kemampuan atau kecakapan yang ada di dalam diri seseorang seperti bakat. Melalui hal tersebut tindakan kreatif muncul dari keunikan keseluruhan kepribadian dalam interaksi dengan lingkungannya.

b. Kreativitas dalam dimensi Process

Upaya mengartikan kreativitas fokus pada proses berpikir sehingga memunculkan ide-ide unik atau kreatif. Menurut pendapat Munandar dalam buku kreatifitas sejarah, teori dan perkembangan (2017: 12), mengatakan bahwa kreativitas adalah sebuah proses atau kemampuan yang mencerminkan kelancaran, keluwesan dan orisinalitas dalam berpikir serta kemampuan untuk mengelaborasi suatu gagasan. Sehingga dapat diambil benang merah suatu kreativitas sebagai sebuah proses yang terjadi di dalam otak manusia dalam menemukan dan mengembangkan sebuah gagasan baru yang lebih inovatif dan variatif.

c. Kreativitas dalam dimensi Press

Pada proses kreativitas yang menekankan faktor "press" atau dorongan, baik dorongan internal diri sendiri berupa keinginan dan hasrat untuk mencipta secara kreatif, maupun dorongan eksternal dari lingkungan sosial dan psikologis. Suatu kreativitas akan kurang berkembang dalam kebudayaan yang terlalu menekankan tradisi dan kurang terbukannya terhadap perubahan atau perkembangan baru.

d. Kreativitas dalam dimensi Products
Kreativitas fokus pada produk atau apa yang dihasilkan dari individu baik sesuatu yang baru (original) atau sebuah kolaborasi (penggabungan) yang inovatif. Penerapan kreativitas pada karya ini lebih menekankan orisinalitas yang bisa dari kombinasi-kombinasi baru yang bermakna sosial tetapi mungkin saja kombinasi yang sudah ada sebelumnya.

Berdasarkan pemaparan di atas pengertian kreativitas terdiri dari empat tahapan, yang mana kreativitas kemampuan merekontruksi ide untuk menyelesaikan masalah, kegiatan dan menciptakan sesuatu karya kreatif yang inovatif (berbeda dengan yang sudah ada) dan variatif (memiliki nilai seni dan nilai tambah) sehingga berharga dan berguna bagi kreator dan orang lain.

Teori pendekatan estetika difungsikan untuk meninjau objek sumber ide penciptaan karya sedangkan teori pendekatan kreativitas ini difungsikan untuk meninjau proses kreatif penciptaan karya.

\section{METODE PENCIPTAAN}

\section{Penelitian berbasis praktek}

Metode penciptaan yang tepat digunakan dalam penciptaan karya ini adalah metode penelitian berbasis praktik (practicebased research). Penelitian berbasis ini mucul sejak tahun 1980-an dan menonjolkan sentra praktikan dalam mengumpulkan keterangan melalui kerja praktik (Malins, Ure, dan Gray, 1996:1). Malins, Ure, dan Gray mendefinisikan konsep practice-based research sebagai penelitian yang dimulai dari kerja praktik dan melakukan praktik, serta penelitian berbasis praktik ini merupakan penyelidikan orisinil yang dilakukan guna memperoleh pengetahuan baru melalui praktik dan hasil praktik, dimana hasil penelitian memberikan penerapan potensial 
sebagai sarana menyampaikan potensi-potensi yang ada pada praktisi Seni Murni dan Kriya.

Mereka menyebutkan dalam laporan mereka bahwa, The Gap: Addressing PracticeBased Research Training Requirements For Designers (Sebuah Celah: Memaparkan SyaratSyarat Penelitian Berbasis Praktik Untuk Perancang) Selain itu, mereka juga memaparkan bahwa:

$$
\text { "...penelitian berbasis praktik }
$$
merupakan penelitian yang paling tepat untuk para perancang karena pengetahuan baru yang didapat dari penelitian dapat diterapkan secara langsung pada bidang yang bersangkutan dan peneliti melakukan yang terbaik menggunakan kemampuan mereka dan pengetahuan yang telah dimiliki pada subjek tersebut" (Malins, Ure, dan Gray, 1996:1).

Proses penciptaan seni kriya dapat dilakukan secara intuitif, tetapi dapat pula ditempuh melalui metode ilmiah yang direncanakan secara seksama, analitis, dan sistematis. Dalam konteks metodologis secara terperinci telah dijelaskan oleh Malins, Ure, dan Gray Dalam skema konsep practice-based research di bawah :

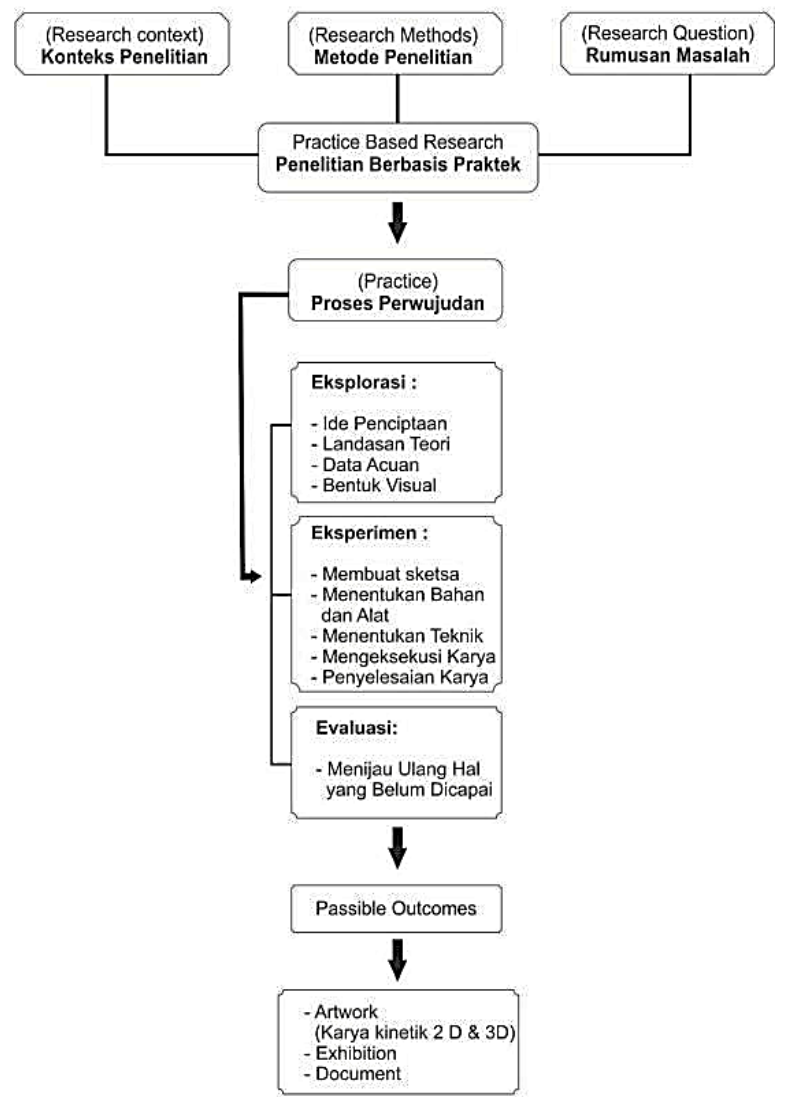

Bagan 1. Mind Mapping Proses Penciptaan Sumber: Practice Based Research Ramlan Abdullah, Jurnal Inti FSSR, 2020.

Dalam penciptaan karya ini diperlukan metode practice-based research atau penelitian berbasis praktik. Yang dilakukan oleh seorang seniman akademis sekaligus menyandang sebagai peneliti dalam peroses berkarya. Candy 2006 (Guntur, 2016:17), menyebutkan bahwa practice-based research adalah suatu upaya penelitian yang orisinil. Dalam memperoleh suatu hal yang baru orisinil dapat dilihat dari hasil artefak yang dihasilkan seperti seni musik, desain, seni digital, pertunjukan dan pameran seni. Candy menyatakan bahwa bila kontribusi pengetahuan menjadi dasar dalam suatu peroses kreatif atau penciptaan ini merupakan suatu peroses dari penelitian berbasis praktik.

Dalam proses penciptaan Tugas Ahir ini practice-based research diangap dapat digunakan dalam proses penciptaan yang 
penulis lakukan. Adanya timbal balik kepada masyarakat dari praktik yang dilkukan berupa metode yang digunakan dalam proses penciptaan, hasil penciptaan dan hasil riset. Setip seniman memiliki peroses atau cara sendiri-sendri dalam peroses penciptaan sebuah karya, penggunaan metode dari ahli yang sama atau dengan ahli yang berbeda.

Karaktereristik praktik secara langsung yang dilakukan setiap seniman satu dengan seniman lainya pasti mmiliki perbedaan. Seperti halnya yang dilakukan oleh candy diatas menjelaskan bahwa orisinil dalam metode penelitian berbasis praktik dapat ditunjukan. Karena seniman dapat mengetahui secara detail peroses peraktik pengerjaan setiap penciptaan sebuah karya seni dan seniman mengalami langsung perktik penciptaan karya seni itu sendri.

$$
\text { Pada penciptaan penulis }
$$
mengumpulkan data-data yang tidak dapat dihasilkan oleh peneliti lain diluar peroses penciptaan karya seni. Seperti yang telah dijelaskan dalam kumpulan jurnal INTI FSSR jilid 18 (2010:44) di menjelaskan bahwa bagian terbaik dari peneliti berbasis praktik adalah manifasi yang tidak dapat dibrikan oleh peneliti murni yang hasilnya berupa tesis temuan, analisis, sintesa, hinga saran dan kesimpulan. Proses ini dapat menghasilkan data berupa artefak sehinga data-data visual ini dapat digunakan sebagai sumber acuan dalam penciptaan sebuah karya visual.

\section{Proses Penciptaan}

Proses penciptaan ini merupakan sebuah proses aktivitas pengolahan rasa dan kemampuan sesuai dengan pengalaman dan pengetahuan yang dimiliki seorang seniman. Melalui proses ini ide konsep dan perwujudan akan dituangkan menjadi karya 2 dimensi dan 3 dimensi yang mampu bergerak dan berinteraksi dengan pengunjung. Pemilihan material meliputi bahan, alat, dan medium akan memiliki peran penting dalam proses penciptaan karya seni. Berikut ini adalah proses-proses tahapan yang sudah dilakukan dalam penciptaan karya.

\section{Tahap Eksplorasi}

Tahapan eksplorasi merupakan proses dimana seniman melakukan masa perenungan (inkubasi) dan meninjau seluas-luasnya segala aspek pendukung konsep penciptaan karya seni. Implementasi eksplorasi dalam karya ini meliputi observasi persiapan dasar dalam mengolah kreativitas berkesenian di lingkungan akademisi. Tahapan yang dilakukan penulis dimulai dengan cara berpikir (merenung), menyimak (melihat dan mendengar), dan membaca (menyimpulkan).

a. Ide (research context)

Eksplorasi tetap bisa difungsikan dan akan terus berjalan sampai tahapan yang ada di dalam proses eksperimen dan eksekusi. Selanjutnya diikuti dengan tahapan awal dalam proses penciptaan yang sangat penting dieksplorasi terlebih dahulu yaitu penggalian sumber ide.

Ide utama penciptaan ini yaitu tentang eksplorasi bentuk Garuda dalam karya kriya kayu. Pada penciptaan ini difokuskan pada bentuk visual dari Garuda yang ditinjau dari segi bentuk dan nantinya akan menciptakan karya bergerak secara dinamis.

b. Data Acuan (research literature)

Pada proses ini penulis melakukan eksplorasi tentang tema penciptaan didasari dari kegiatan pengamatan yang dilakukan melalui data seperti, mencari literatur yang relevan dari buku, internet, dan observasi langsung pada objek Garuda. Literatur yang dicari oleh penulis data yang berkaitan dengan Garuda seperti dalam buku karya Nanang R. Hidayat yang 
berjudul "Mencari Telur Garuda", sementara dalam wetografi mengenai seni kinetik dan Garuda melalui blogger, artikel, majalah daring, dan website yang berkaitan dengan penciptaannya. Selain hal tersebut dilakukan observasi langsung yaitu, mengamati secara langsung arca patung Garuda yang ada di komplek Candi Prambanan dan mengamati beberapa patung garuda yang ada disetiap sudut pertigaan maupun perempatan.

Selain melakukan eksplorasi di atas penulis juga melakukan observasi penggunaan material yang akan dipakai sebagai media perwujudan karyanya. Hal tersebut dilakukan untuk memperoleh hasil wujud karya yang diharapakan penulis. Setelah melakukan observasi akhirnya pemilihan material kayu dipilih kayu jati sebagai material yang digunakan. Kayu jati dipilih mempertimbangkan kualitas karakter kayu jati yang memiliki serat yang bagus dan dapat menyesuaikan visual yang ingin wujudkan.

c. Landasan teori (research theory)

Adalah proses mencari teori pendekatan yang akan digunakan sebagai acuan konsep penciptaan karya dalam mewujudkan bentuk karya seni kinetik. Teori-teori yang digunakan juga dapat membantu membedah hasil karya. Teori yang dipakai dalam penciptaan karya ini adalah teori pendekatan Estitk, teori pendekatan Kreativitas dan fenomenologi. Berangkat dari pengalaman-pengalaman penulis dalam mengolah apa yang telah dirasakan terhadap fenomena lingkungan, alam, media sosial dan pengalaman pribadi yang diwujudkan kedalam sebuah karya seni kinetik.

\section{Eksperimen}

Adalah peroses dimana penulis melakukan percobaan dan mengolah bahan dan juga mengelolah sumber ide kedalam bentuk yang akan diwujudkan. Perancangan bentuk dan konsep karya kedalam bentuk seketsa atau desain alternatif. Berdasarkan hasil analisis data acuan yang dilakukan, dapat ditarik kesimpulan dalam untuk digunakan membuat rancangan karya. Berikut ini adalah gambar rancangan karya yang akan diwujudkan dalam penciptaan Tugas Ahir ini Berikut adalah sketsa alternatif dan desain terpilih yang telah penulis ciptakan.

a. Bentuk

Setelah tahapan ekspolasi, dilanjutkan pada tahapan perancangan yaitu pembuatan sketsa dan desain, hal ini dilakukan agar bantuk Garuda dapat terbentuk secara sistematik hingga memperoleh desain yang diingin dalam proses perwujudan karya. Sketsa dan desain digunakan sebagai bahan acuan, agar mempermudah dalam proses perwujudannya.

Melalui tahapan sketsa dan desain tidak menutup kemungkinan akan menghasilkan suatu ide yang dapat menciptakan sutau wujud visual Garuda lebih menarik. Pada tahapan awal ini akan dilakukan pembuatan sketsa mengacu pada gagasan bentuk dan karakteristik dari Garuda melalui pengolahan data yang akan dipadukan dengan ide dari penulis. Data yang diperoleh dicermati dan digunakan sebagai bahan eksplorasi pada pembuatan sketsa dan desain. Berikut ini adalah beberapa perencanaan karya yang akan di awali dengan pembuatan sketsa terpilih. 

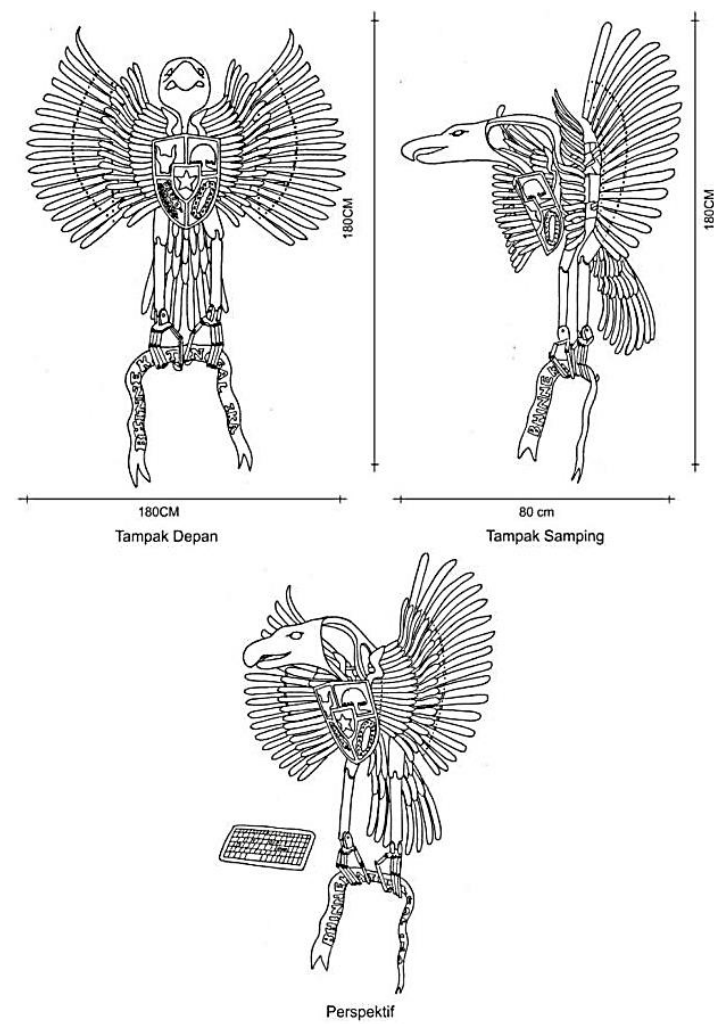

Gambar 10. Sketsa kerja karya 1 Judul: STOP Hoax

Foto: Dedy Shofianto, 2020
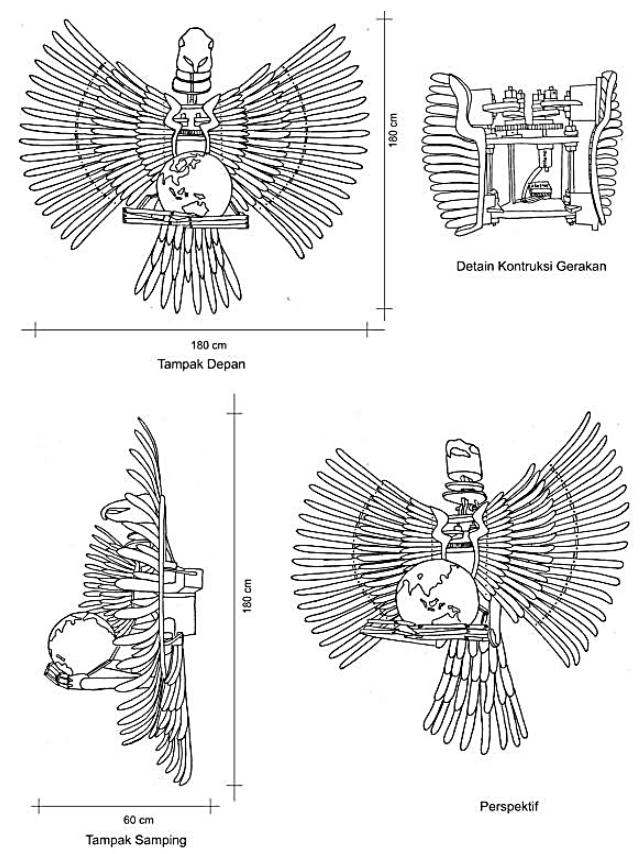

Gambar 11. Sketsa kerja karya 2 Judul: Garuda Jadilah Dirimu Bagian Dari Dunia Yang Terus Bergerak Dan Berputar Foto: Dedy Shofianto, 2020

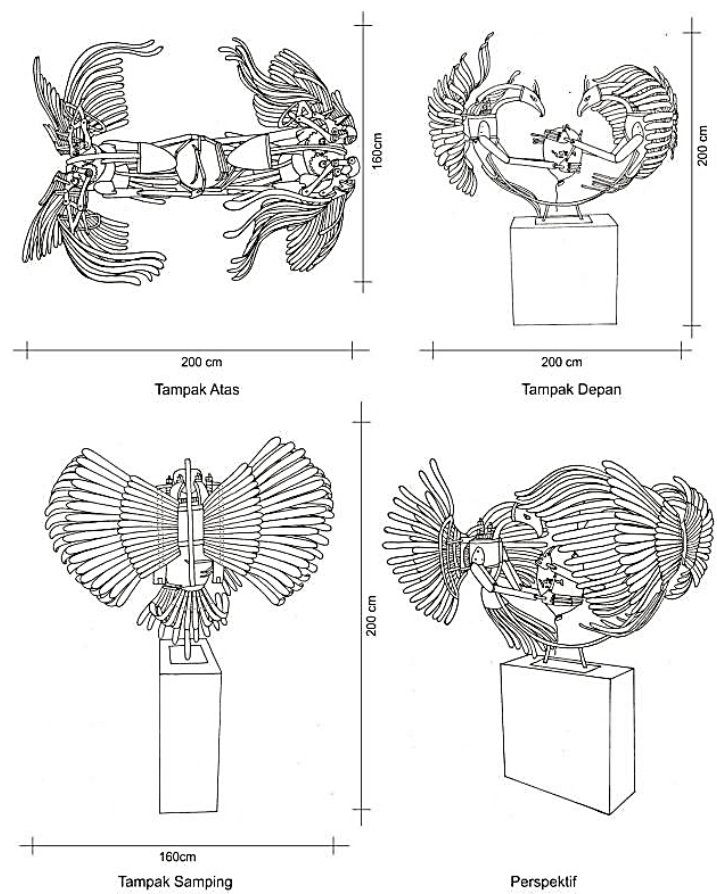

Gambar 12. Sketsa kerja karya 3 Judul: Menjagamu!!! (Indonesia) Foto: Dedy Shofianto, 2020

1. Pemilihan material kayu

Bahan utama dalam proses perwujudan semua karya ini yaitu kayu jati merupakan kayu yang berasal dari pohon jati dengan kualitas tinggi. Kayu ini memiliki tekstur dan serat yang halus dan padat, dengan pola yang kecil yang menampilkan keindahan dari kayu jati. Dalam bahasa ilmiah pohon jati disebut Tectona grandis. Permukaan kayu jati berwarna cokelat, serta memiliki keras sedang. Untuk harga kayu jati termasuk kayu dengan kulitas tinggi hingga harganya lebih mahal dari pada kayu lainnya, masyarakat sering menggunakan kayu jati sebagai bahan utama produksi mebel hal ini dikarenakan kayu ini sangat bagus dan memiliki ciri khas tertentu. Menurut Martawijaya et al. (2005) dalam jurnal ilmu pertanian Indonesia (Wahyudi dkk, 53:2014). kayu jati tua memiliki ciri-ciri batas lingkaran tumbuh sangat jelas, parenkim batasnya tegas berupa pita-pita konsentris yang lebar, permukaan kayu licin 
berlilin, mengkilap, keras, dan berbau khas mirip zat penyamak kulit. Kayu jati memperlihatkan lingkaran tumbuh dan parenkim batas pada kayu jati tua serta perbedaan proporsi bagian kayu teras antara kayu jati tua dan kayu jati unggul.

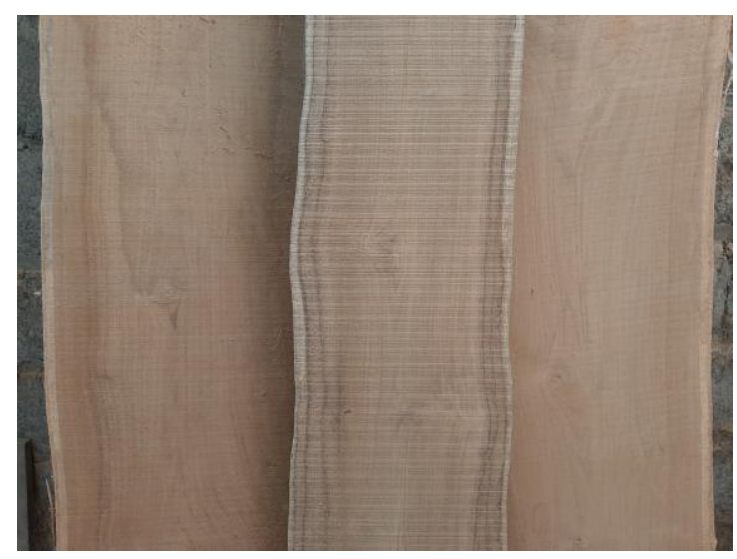

Gambar 13. Kayu Jati

(Foto: Dedy Shofianto, 2018)

\section{Pembuatan pola potongan}

Proses ini merupakan proses membuat pola bagian-bagian robot yang akan dirangkai. Pola ini nantinya akan dipindahkan pada kayu dan dipotong sesuai dengan bentuk yang diinginkan.

\section{Penerapan teknik yang digunakan}

Teknik utama yang digunakan dalam pembuatan karya ini ada tiga macam, yaitu teknik potong (cutting), teknik bubut, dan teknik konstruksi kayu. Teknik potong menjadi teknik yang paling banyak digunakan dalam proses penciptaan karya ini. Teknik bubut diterapkan untuk membuat bagian karya yang berbentuk silinder yang nantinya akan dikombinasikan dengan teknik potong, dan dirangkai menjadi satu menggunakan teknik konstruksi kayu. Proses perwujudan terdiri dari proses pembuatan sketsa dan desain, yang dilanjutkan dengan proses kerja bangku. Proses kerja bangku merupakan proses pengerjaan dengan menggunakan mesin, yang antara lain adalah mesin gergaji skrol (scroll saw), gergaji bundar (circle saw), mesin bubut (wood lathe). Setelah semua bagian terpotong, dilanjutkan dengan proses perakitan dan finishing.

4. Finishing

Tahap finishing yang dilakukan pertama kali adalah menghaluskan permukaan kayu dengan menggunakan amplas. Amplas yang digunakan adalah amplas kain, jenis alumunium oxide, ukuran 60, 240, 400 dan 1.000. Amplas digunakan untuk menghaluskan kayu sebelum di finishing. Amplas yang digunakan dalam proses penciptaan karya seni ini adalah amplas kain alumunium oxide merk SIA dan Taiyo. Ukuran amplas yang digunakan ada 4 jenis, yaitu ukuran 60, 240, dan 400 dan 1.000. Ukuran 60 adalah ukuran amplas kasar, digunakan untuk menhilangkan bagian-bagian menonjol. Ukuran 240 merupakan ukuran sedang yang digunakan untuk penghalusan tahap ke-2. Sedangkan ukuran 400, ukuran yang halus digunakan sebagai penghalusan tahap ke-3, yaitu sebelum peroses tahap terakhir menggunakan amplas 1.000, Ukuran 1.000 merupakan tahap pengamplasan terakhir sebagai tahap proses sangkling. Sangkling adalah teknik fininising dengan cara menggosok kayu dengan kayu atau dengan daun pisang yang kering untuk memunculkan tekstur serat kayu sehingga hasil yang diperoleh terkesan alami. 
HASIL

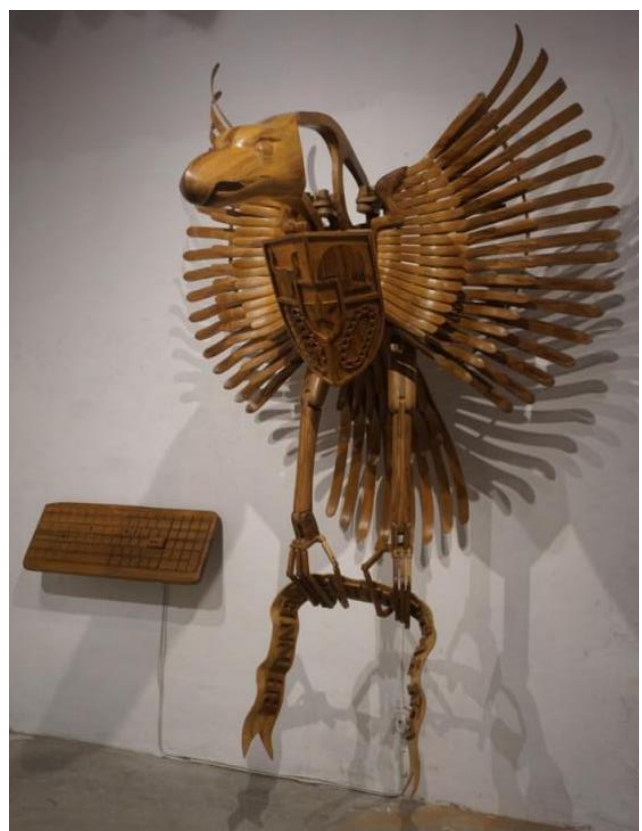

Gambar 14.

Judul: Garuda di Galeri Pascasarjana ISI Yogyakarta ( Judul karya ini mengikuti dimana karya ini di pasang)

Bahan: mix media (kayu jati, besi kuningan, stailess steel, dinamo DC, perangkat elektronik, sensor gerak)

Teknik: ukir, kerja bangku, sekrol saw Ukuran: $80 \mathrm{~cm} \times 180 \mathrm{~cm} \times 180 \mathrm{~cm}$ Finishing: sangkling

Tahun : 2019

Fotografer: Dedy Shofianto

Tinjauan karya :

Pada karya ini adalah karya tiga dimensi yang menggunakan kayu jati sebagai bahan uatam yang dipadukan dengan prinsip mekanik yaitu seni kinetik.

Gerak yang dihasilkan karya ini merupakan unsur utama dari karya secara visual, bentuk, dan warna. Dalam proses pengerjaan menggunakan beberapa teknik seperti pahat, sekrol saw, bubut, mekanik, elektronik dan sebagainya. Sementara teknik penyelesaian karya ini menggunakan teknik sangkling, dan penghalusan dengan menggunakan amplas kertas sehingga dapat memberikan efek alami pada karya. Setelah itu karya dilapisi natural wax untuk menghilangkan debu yang menempel pada kayu.

Karya berjudul "Garuda" yang menyesuaikan penempatan karya ini ditempatkan. Ide dasar dari karya ini adalah memberikan informasi yang jelas dan benar. Hal ini berhubungan dengan fenomena yang terjadi di dunia maya, banyak berita Hoax atau bohong yang memberikan informasi yang tidak valid. Berita yang tersebat itu sangat memberikan suatu kegelisan bagi masyarakat, dimana berita tersebut terkadang mengatasnamakan agama, sosial, budaya ataupun politik. Hal ini dapat menimbulkan suatu bentuk ancaman ke satuan antar bangsa dan negara.

Melalui hal tersebut karya ini mengajak para seniman, penikmat seni, pencinta seni, dan masyarakat luas untuk berinteraksi secara langsung dengan cara menekan tombol enter pada keyword yang tertulis stop hoax. Tujuan utama melakukan hal ini, sebagai bentuk ajakan supaya jangan menyebarkan hoax, agar tidak terjadi perpecahan antara suku, bangsa, dan negara di Indonesia.

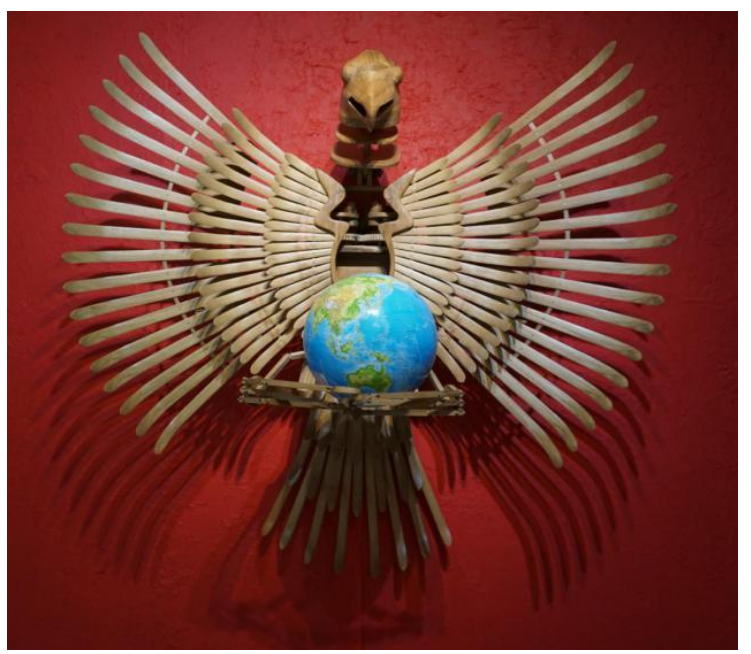

Gambar 15.

Judul: "Garuda! Jadilah Dirimu Bagian Dari Dunia Yang Terus Bergerak Dan Berputar"

Bahan: mix media (kayu jati, besi kuningan, stailess steel, dinamo DC, perangkat elektronik, sensor gerak)

Teknik: ukir, kerja bangku, sekrol saw 


\author{
Ukuran: $60 \mathrm{~cm} \times 180 \mathrm{~cm} \times 180 \mathrm{~cm}$ \\ Finishing: sangkling \\ Tahun: 2018 \\ Fotografer: Dedy Shofianto
}

Tinjauan karya:

Sama hal dengan karya sebelumnya, karya ini menggunakan bahan utama kayu jati dalam penciptaan karya dengan menggunakan beberapa teknik dalam kriya kayu seperti teknik ukir, sekrol saw, kerja bangku. Sementara teknik untuk menghasilkan gerakan menggunakan teknik mekanik dan dibantu oleh dinamo DC sebagai penggeraknya. Selain itu karya ini dilengkapi dengan sensor yang berfungsi agar pengunjung dapat berinteraksi langsung dengan karya ini.

Dengan judul "Garuda! Jadilah Dirimu Bagian dari Dunia yang Terus Bergerak dan Berputar", makna karya ini yaitu dalam perkembang teknologi yang semakin pesat dan cepat diseluruh dunia. Kehidupan dulu dan sekarang mengalami suatu perubahan bila kita tak bergerak dengan cepat, maka akan tertinggal jauh dengan perkembangan yang ada. Perkembangan tersebut tidak dapat dihindari, bila kita tidak dapat menyikapi dengan benar dan baik akan tergerus akan waktu dan lupa dengan jati diri kita sendiri. perkembangan zaman bukan hanya pada teknologi akan tetapi, bahasa, budaya, busana, tradisi, sosial, ekonomi, politik, dan banyak lagi. Hal ini dapat mempengaruhi ideologi suatu negara tak terkecuali bangsa Indonesia, bila bukan generasi kita siapa lagi yang akan mempertahankannya.

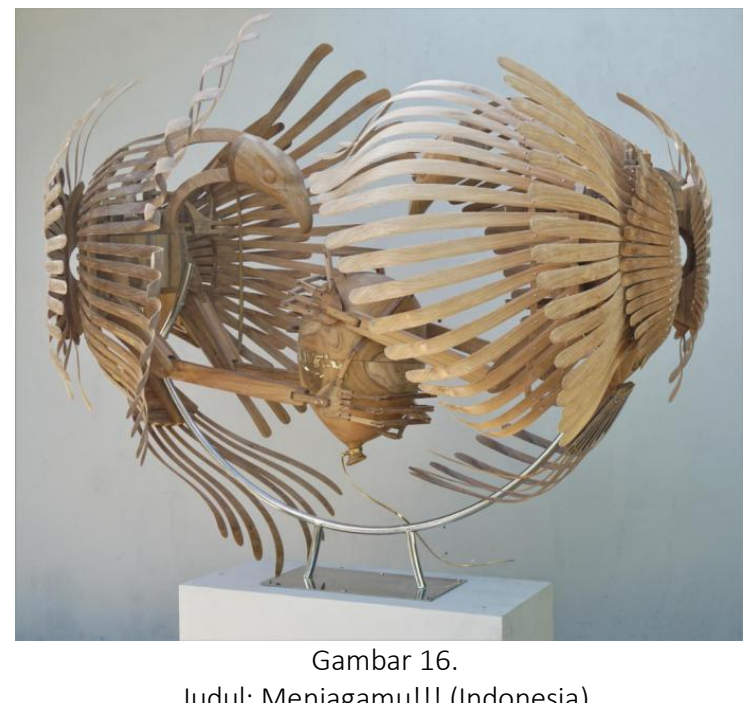

Bahan: mix media (kayu jati, besi kuningan, stailess steel, dinamo DC, perangkat elektronik, sensor gerak)

Teknik: ukir, kerja bangku, sekrol saw Ukuran: $200 \mathrm{~cm} \times 160 \mathrm{~cm} \times 200 \mathrm{~cm}$ Finishing: sangkling Tahun : 2020

Fotografer: Dedy Shofianto

Tinjauan karya:

Pada karya ini dapat dilihat secara visual menggunakan pergabungan media dari kayu jati, besi kuningan, stailess steel, dinamo DC, perangkat elektronik, serta sensor gerak. Dalam karya ini teknik yang digunakan pada proses pengerjaannya yaitu, teknik ukir, kerja bangku, sekrol saw, dan bubut. Sementara teknik untuk menghasilkan gerakan menggunakan teknik mekanik. Warna dalam karya tetap mempertahankan warna dari kayu, hal ini dilakukan untuk menghasilkan efek alami pda karya.

Judul karya ini yaitu "Menjagamu!!!", deskripsi karya terlihat dua burung Garuda menyerupai burung elang Jawa yang sedang berhadapan, bila diamati terdapat balon ditengah antara ke burung 1 dan 2 yang seolah-oleh sedang merebuatkan balon tersebut. Balon bila diamati lebih dekat terlihat peta Indonesia pada bagian depan balon yang diberi warna emas. Makna yang ingin 
disampaikan dalam karya ini yaitu, adanya suatu fenomena bangsa Indonesia merampas dan merebutkan yang bukan haknya. Walaupun sebenarnya adanya maksud yang baik untuk merawat Indonesia. Agar hal itu dapat terjadi, kita rakyat Indonesia tidak dapat menemukan solusi yang baik. Hal yang perlu dilakukan kita sebagai bangsa Indonesia yaitu menjaga, jangan sampai terjadi suatu ledakan yang mengakibatkan perpecahan.

\section{KESIMPULAN}

Hal yang ingin diulas dalam penciptaan "Burung Garuda Dalam Seni Kriya" ini cara merepresentasikan karya dengan meperhatiakn nilai estetika, nilai historis, dan makna filosofis yang dihasil dalam karya Garuda ini. Sementa itu penulis hal tersebut penulis ingin mengulas proses kreatif dan proses perwujudan karya dengan menggunakan seni kinetik dalam penciptaannya.

Proses penciptaan diatas merupakan proses yang dilakukan sebagai tahap penyelesaian Tugas Akhir. Tahap penciptaan yang dilakukan mulai dari eksplorasi ide. Ide utama dari karya yang dibuat adalah bentuk Burung Garuda ke dalam seni kriya.Penuangan ide ke dalam bentuk sketsa dan desain menjadi pengantar terwujudnya ide menjadi sebuah karya seni.Perwujudan adalah tahap paling berpengaruh atas terciptanya sebuah karya seni yang memiliki nilai tanda dan jaringan makna.

Penciptaan ini menghasilkan 3 karya seni kriya, 2 karya dua dimensi dan 1 karya tiga dimensi. Menghasilkan karakter baru dari burung Garuda, sebagai hasil dari proses deformasi, yaitu berupa burung Garuda kedalam karya seni kinetikdengan meperhitungkan gerakan yang dihasilkan.

Berdasarkan apa yang telah dilakukan, terjadi beberapa kendala yang sedikitnya mempengaruhi proses dari penciptaan. Mulai dari kendala teknis yaitu dalam proses finishing proses ini menggunakan teknik sangkling, sehinggga perlu bongkar pasang karya yang sudah bisa bergerak harus dibongkar terlebih dahulu untuk proses penyangklingan kemudian baru bisa dirangkai menjadi satu kesatuan, karena kerumitan-kerumitan bagian yang di sangkling.

Dengan terciptannya karya-karya ini, semoga dapatmenjadibahankajian, diskusi, ataupun kritikan. Dapat juga memperkaya khasanah seni kriya dalam pendidikan seni.

\section{Daftar Pustaka}

Abdullah, Hamidin. (2010), Jurnal Perintis Pendidikan Fakulti Seni Lukis dan Seni Reka (UiTM), Editorial Journal INTI FSSR INTI Jilid 18 (Bil.1).

Chen, G.-D., Lin, C.-W., \& Fan, H.-W. (2015), The History and Evolution of Kinetic Art. International Journal of Social cience and Humanity.

Gustami,SP., (2004), "Proses Penciptaan Seni Kriya: Untaian Metodologis", Program Pascasarjana S2 Penciptaan Dan Pengkajian Seni ISI Yogyakarta.

Hidayat, Nanang R. (2008), Mencari Telur Garuda. Jakarta: Nalar.

Ismanto, An.Sains Leonardo. (2005). "Menguak kecerdasan terbesar Masa Renaisans" Yogyakarta: Jalasutra Anggota IKAPI.

Iswantara, Nur. (2017), Kreativitas (sejarah, teori dan perkembangan), Gigih pustaka Mandiri.

Kartika, Dharsono Sony. (2004), SeniRupaModern, Bandung: Rekayasa Sains.

Langer, Suzanne K, (2006), Problematika Seni, Bandung: Sunan Ambu Press. Oentoro, 
Y. (2013). Representasi Figur Burung Garuda yang Digunakan sebagai Lambang Negara. Nirmana

Pasha, Musthafa Kamal. (2003) Pancasila dalam Tinjauan Historis Yuridis dan Filosofis, Citra arsa Mandiri, Yogyaarta.Scheneckenburger, M. Walter F Ingo (2005). Art of the $20^{\text {th }}$ Century, Volume 1 \& 2: Taschen GmbH.Sani, Fitri

Lestari. (2015), fenomena Komunikasi anggota Komunitas Graffiti di Kota Medan (Studi Fenomenologi Pada Anggota Komunitas ME \& ART), Jom FISIP, Vol. 2, No.1.

Soekatno. (1992). Mengenal Wayang Kulit Purwo. Semarang: Aneka llmu.

Sudarmaji, (1979), Dasar-dasar Kritik Seni Rupa, Dinas Museum dan Sejarah, Jakarta.

Soedarso, SP. (1990), TinjauanSeni: Sebuah Pengantar untuk Apresiasi Seni, Yogyakarta: Saku Dayar Sana. 2000. Sejarah Perkembangan Seni Rupa Modern. Jakarta: Studio Delapan Puluh.

Susanto, Mikke. (2011), Diksi Rupa: Kumpulan Istilah Dan Gerakan Seni Rupa, Yogyakarta: Dicti Art Lab dan Djagad Art House.

Zaelani, Rizki. (2011), "Kinetic Art". Edwinsgallery.com. 10.20 am 15 Mei 2020.

\section{Webtografi}

http://edwinsgallery.com/kinetik_perkembanga n.php akses 13 Januari 2014 jam 22:40 WIB.

http://senikinetic.tumblr.com/.akses 22 juni 2015 jam 10:26 WIB https://tribakti10.blogspot.co.id/2015/11/pen cipta-lambang-negara-republik.html. akses 2 Oktober 2017 22:30 WIB

http://phdi.or.id/artikel/garuda-panca-silabagi-umat-hindu.akses2 Oktober 2017 22:30 WIB

http://indoartnow.com/artists/edwinrahardjo.akses 24 otober 2017 21:30 WIB

http://businesslounge.co.id/2014/10/30/sekila s-karya-karya-menarik-dalampameran-trienalversi/.akses 24 otober 2017 21:30 WIB

https://singaporeguidebook.com/2018/07/09/ strandbeests-hasil-karya-theo-jansendipamerkan-di-singapura/, 2020. 